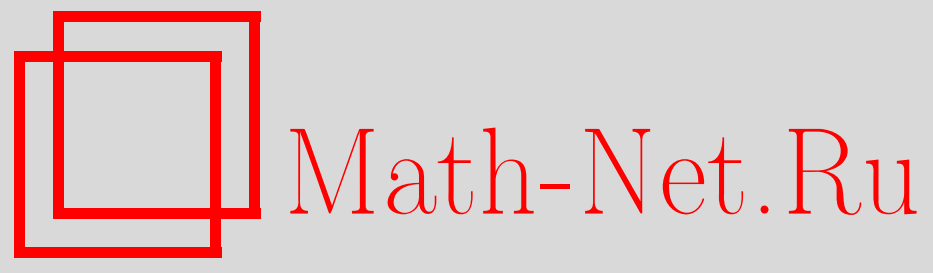

Д. М. Гуреев, Медико-биологические аспекты лазерного воздействия, Вестн. Сам. гос. техн. унma. Сер. Физ.-мат. науки, 2013, выпуск 3(), 119 128

DOI: https://doi.org/10.14498/vsgtu1235

Использование Общероссийского математического портала MathNet.Ru подразумевает, что вы прочитали и согласны с пользовательским соглашением

http://www.mathnet.ru/rus/agreement

Параметры загрузки:

IP: 3.82 .47 .9

26 апреля 2023 г., 18:26:33

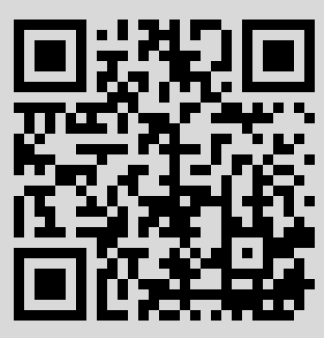




\section{УДК 544.032.65:577.1}

\section{МЕДИКО-БИОЛОГИЧЕСКИЕ АСПЕКТЫ ЛАЗЕРНОГО ВОЗДЕЙСТВИЯ}

\section{Д. М. Гуреев}

Самарский государственный технический университет, Россия, 443100, Самара, ул. Молодогвардейская, 244.

E-mail: anton_gureev@samaradom.ru

Экспериментально изучен характер распределения коэффициентов отражения и пропускания излучения различных длин волн биологическими тканями. Дано физическое обоснование подходов к оптимизачии выбора лазерных источников и условий их практического применения для решения фундаментальных и прикладных задач медико-биологических исследований.

Ключевые слова: лазерное излучение, коэфбищиенты отражсения и пропускания, биологические ткани.

Введение. В настоящее время широкое развитие получила лазерная медицина, в основе которой лежит эффективное использование уникальных свойств лазерного излучения, таких как высокие монохроматичность, направленность, яркость, в хирургии, терапии, диагностике $[1,2]$. В медикобиологических исследованиях важное место также отводится изучению влияния лазерного излучения на наследственность растений с целью повышения урожайности сельскохозяйственных культур [3]. В лазерной терапии, диагностике, селекции растений преимущественно используется излучение гелийнеонового лазера (длина волны излучения 0,633 мкм - красная область спектра) низкой интенсивности $\sim 10^{-1} \mathrm{Bт} / \mathrm{cm}^{2}$, сопоставимой с интенсивностью излучения Солнца во всей его широкой области спектра на поверхности Земли в ясный солнечный день. Вместе с тем имеются также примеры успешного практического применения излучения аргонового лазера (длина волны излучения 0,488 и 0,515 мкм - сине-зеленая область спектра), в частности для лечения сосудистой патологии. Основу последнего составляет избирательный характер поглощения гемоглобином крови излучения сине-зеленой области спектра. Выбор гелий-неонового лазера в качестве основного инструмента в медико-биологических исследованиях с использованием лазерного излучения обосновывается наибольшей глубиной проникновения излучения красной и ближней инфракрасной областей спектра в биологические ткани. Однако при этом несколько в стороне остается вопрос: насколько оправданным является такой выбор с точки зрения эффективности взаимодействия излучения данных областей спектра с биологическими тканями?

Целью данной работы является экспериментальное изучение характера распределения коэффициентов отражения и пропускания излучения различных длин волн биологическими тканями и физическое обоснование подходов к оптимизации выбора лазерных источников и условий их практического применения в медико-биологических исследованиях.

Дмитрий Михайлович Гуреев (д.ф.-м.н., проф.), профессор, каф. общей физики и физики нефтегазового производства. 
Материалы и методики эксперимента. В качестве исследуемых биологических тканей использовались срезы большинства плодовых и овощных культур, разнообразные ягодные и зерновые культуры, кисть руки человека, а также разновидности почв (чернозем, песок, глина и их смеси), вода. Коэффициенты отражения измерялись на фотометре отражения ФО-1 в диапазоне длин волн излучения 0,364-0,927 мкм. Оптическая схема фотометра отражения приведена на рис. 1. Принцип её работы состоит в следующем. Излучение от источника света 1 (галогенной лампы КГМ 6,3-15) попадает на конденсор 2, который переносит изображение источника в плоскость полевой диафрагмы 3. Полевая диафрагма 3 устраняет влияние бликов колбы источника света. После полевой диафрагмы 3 световой пучок проходит сменную диафрагму 4, изображение которой с помощью объектива 5 и зеркала 10 переносится в плоскость измеряемого образца 11. В зависимости от размера измеряемого образца диаметр светового пятна в его плоскости может изменяться и принимать значения 30,18 и 12 мм.

Зеркало 10, расположенное внутри фотометрического шара 8, может поворачиваться вокруг оси и занимать три фиксированных положения:

1) калибровка-1 - световой поток отражается от плоской поверхности зеркала на внутреннюю стенку шара;

2) калибровка-2 - световой поток отражается от сферической поверхности зеркала на внутреннюю стенку шара;

3) измерение - световой поток отражается плоской поверхностью зеркала в плоскость измеряемого образца 11 или светоловушку 12.

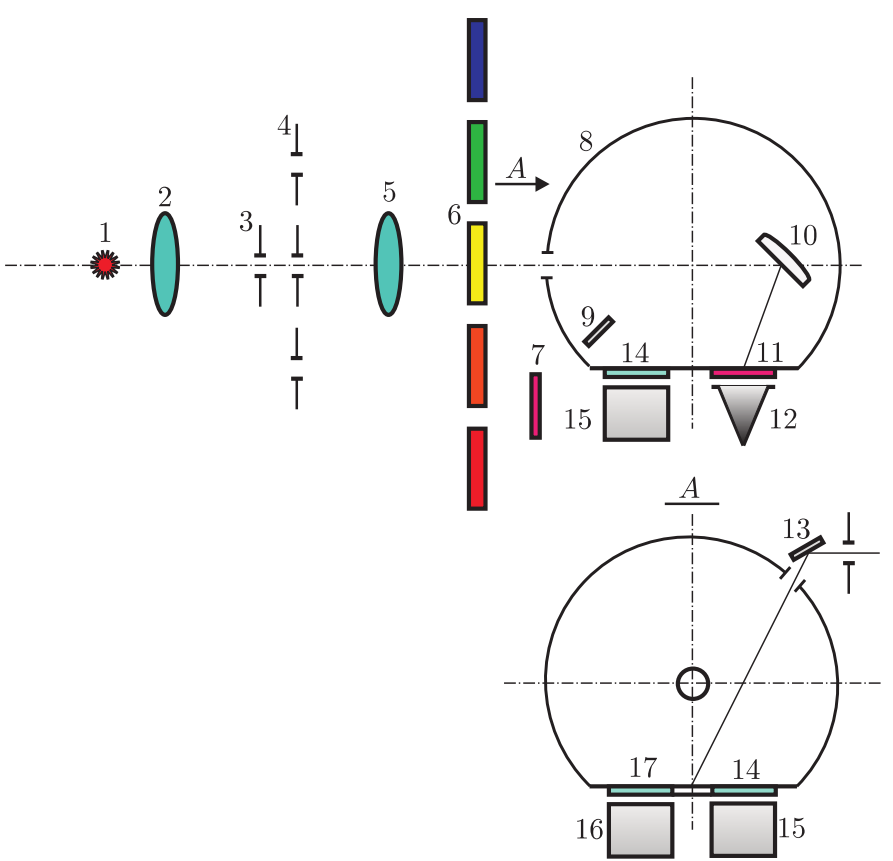

Рис. 1. Оптическая схема фотометра отражения ФО-1: 1 - источник света; 2 - конденсор; 3 - полевая диафрагма; 4 - сменные диафрагмы; 5- объектив; 6 - светофильтры; 7, 11 - измеряемые образцы; 8 - фотометрический шар; 9 - экран; 10, 13 - зеркала; 12 - светоловушка; 14,17 молочные стёкла; 15, 16 - приёмники излучения 
Свет, рассеянный в шаре, поступает на приемники излучения 15, 16 через окна, закрытые молочными стеклами 14, 17. В качестве приемников излучения служат фотоумножитель ФЭУ-4 и фотодиод ФД-24K для областей спектра 0,364-0,750 мкм и 0,750-0,927 мкм соответственно.

В случае измерения коэффициента пропускания диффузно рассеивающих образцов 7 вводится экран 9, который предохраняет приемники излучения от попадания на них рассеянного непосредственно образцами света.

Для выделения узких участков спектра поочередно вводятся светофильтры 6. В состав фотометра отражения входят двенадцать светофильтров, из них один для ближней ультрафиолетовой области спектра (0,364 мкм), шесть для видимой области спектра $(0,400 ; 0,457 ; 0,490 ; 0,520 ; 0,582 ; 0,620$ мкм), четыре для ближней инфракрасной области спектра $(0,750 ; 0,832 ; 0,874$; 0,927 мкм) и один корригирующий светофильтр для приведения спектральной чувствительности фотоумножителя к относительной видности глаза.

Зеркало 13 установлено для наблюдения за положением измеряемого образца.

Для измерения коэффициентов пропускания использовались оптические схемы, приведенные на рис. 2 и 3. В схеме рис. 2 в качестве источника света 1 служила двухсотваттная вольфрамовая лампа накаливания, излучение которой фокусировалось линзой 2 с фокусным расстоянием 100 мм на входном отверстии болометрического приемника излучения ПИП-1 5 измерителя мощности ИМО-3 6. Непосредственно перед входным отверстием болометрического приемника излучения ПИП-1 5 располагались светофильтр 3 и измеряемый образец 4. Для перекрытия области спектра от ближней ультрафиолетовой до ближней инфракрасной было выбрано восемь светофильтров [4]: ПС11 (0,320 мкм), ФС6 (0,373 мкм), СС8 (0,410 мкм), 3С8 (0,529 мкм), ЖКС18 (0,600 мкм), OC14 (0,620 мкм), KC15 (0,700 мкм), ИKC5 (1,240 мкм).

В этой же схеме измерялись коэффициенты пропускания излучения полупроводникового лазера с длиной волны 0,630-0,680 мкм.

В схеме рис. 3 в качестве источника света использовался гелий-неоновый лазер 1, излучение которого через объектив 2 вводилось в оптоволокно 3, транспортировалось по нему к измеряемому образцу 4 и регистрировалось с помощью фотодиода ФД-245 и вольтметра 6.

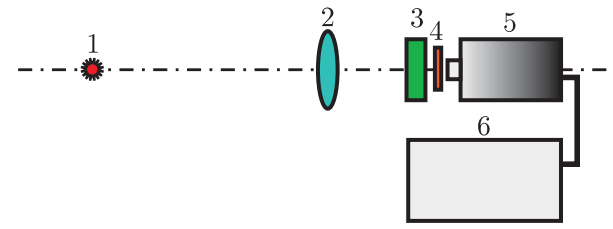

Рис. 2. Оптическая схема измерения коэффициентов пропускания излучения в диапазоне длин волн от ближней ультрафиолетовой до ближней инфракрасной области спектра: 1 - источник света, 2 - фокусирующая линза, 3 - светофильтр, 4 - измеряемый образец, 5-болометрический приемник излучения ПИП-1, 6- измеритель мощности излучения ИМО-3

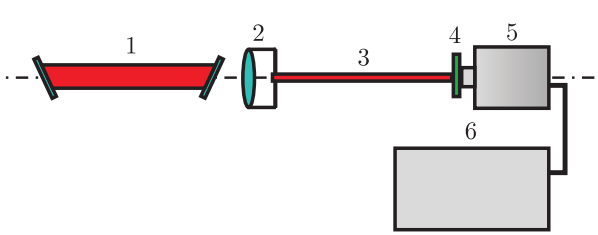

Рис. 3. Оптическая схема измерения коэффициентов пропускания излучения гелийнеонового лазера: 1 - гелий-неоновый лазер, 2 - объектив, 3 - оптоволокно, 4 - измеряемый образец, 5 - фотодиод ФД-24, 6 - вольтметр 
Результаты и их обсуждение. Примеры полученных экспериментальных зависимостей коэффициентов отражения $R$ от длины волны излучения $\lambda$ приведены на рис. 4 и 5. Характерной особенностью данных зависимостей является возрастание коэффициентов отражения в диапазоне длин волн 0,3640,800 мкм и их последующее уменьшение при $\lambda>0,800$ мкм. Выявленные закономерности являются общими, на что, в частности, указывает хорошее совпадение полученных нами результатов для кисти руки человека (рис. 6) с результатами для кожного покрова человека [5], приведенными на рис. 7.

Столь же общими являются и зависимости коэффициентов пропускания $T$ от длины волны излучения $\lambda$, приведенные на рис. 8 и 9. Эти зависимости указывают на то, что коротковолновое излучение глубже проникает в биологические ткани, но при этом и доля поглощения его оказывается больше. Последнее следует из сопоставительного анализа кривых отражения и пропускания. Особо обращает на себя внимание сине-зелёная область спектра, в которой регистрируется возрастание коэффициентов пропускания при одновременном замедлении в росте или даже уменьшении коэффициентов отражения.

Для одних и тех же биологических тканей коэффициенты пропускания возрастают с увеличением мощности излучения (рис. 10) и уменьшением оптической плотности (разрыхлением) биологических тканей (рис. 11).

Анализ особенностей поведения кривых отражения и пропускания позволяет предположить, что в их основе лежат глубокие физические причины, обусловленные влиянием излучения Солнца на биосферу Земли. Действительно, к настоящему времени собрано достаточное количество фактов [6-9], свидетельствующих о том, что любой живой организм, как и вся биосфера Земли в целом, по-своему служат избирательными резонаторами и трансформаторами солнечной активности. Жизнь на Земле возникла и развивалась благодаря солнечной энергии в течение нескольких миллиардов лет. Поэтому, как справедливо впервые отметил профессор А. Л. Чижевский, каждая живая клетка по существу представляет собой своеобразный трансформатор, преобразующий энергию Солнца в тепловую, механическую, электрическую, химическую и другие энергии. И именно спектр излучения Солнца, под действием которого сформировались устойчивые жизненные циклы клеток, должен проявляться в избирательном характере процессов взаимодействия световых потоков с биологическими тканями.

Спектр излучения Солнца [10] приведен на рис. 12. Видно, что его максимум приходится на сине-зелёную область. Это в соответствии с законом смещения Вина [11]

$$
T_{\mathrm{L}} \lambda_{\max }=b,
$$

где $T_{\text {ц }}$ - цветовая температура, $\lambda_{\max }$ - длина волны, при которой наблюдается максимум спектра излучения, $b \approx h c /(4,965 k)=2,898 \cdot 10^{-3} \mathrm{M} \cdot \mathrm{K}$ - постоянная Вина; $h=6,626 \cdot 10^{-34}$ Дж·с - постоянная Планка; $c=2,998 \cdot 10^{8} \mathrm{~m} / \mathrm{c}-$ скорость света в вакууме; $k=1,380 \cdot 10^{-23}$ Дж/K - постоянная Больцмана, позволяет оценит цветовую температуру на поверхности Солнца $\sim 6 \cdot 10^{3} \mathrm{~K}$ $\left(\lambda_{\max } \approx 0,480 \mathrm{MKM}\right)$.

Отметим, что в отличие от спектра излучения Солнца максимум спектра излучения вольфрамовой лампы накаливания, использованной нами в схеме 


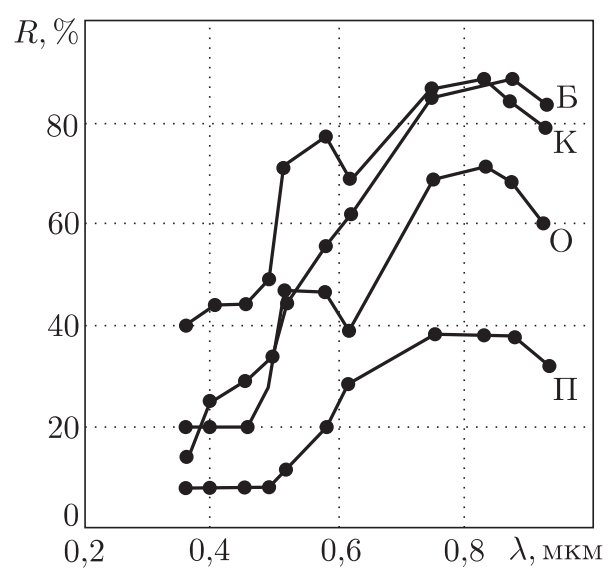

Рис. 4. Зависимости коэффициентов отражения $R$ от длины волны излучения $\lambda$ для кабачков $(\mathrm{K})$, баклажанов (Б), помидоров (П), огурцов (О)

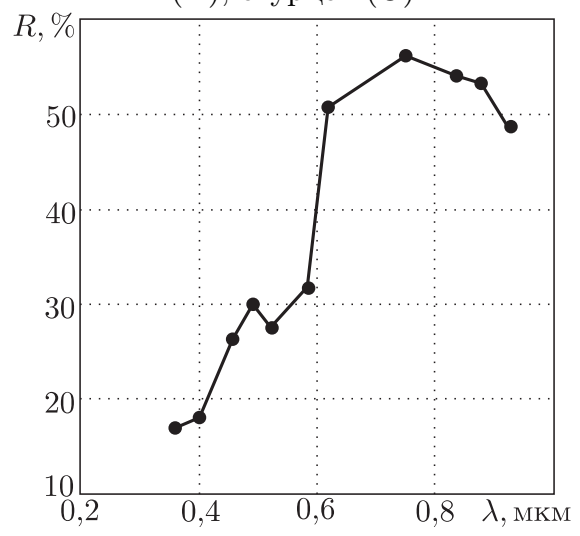

Рис. 6. Зависимость коэффициента отражения $R$ от длины волны излучения $\lambda$ для кисти руки человека

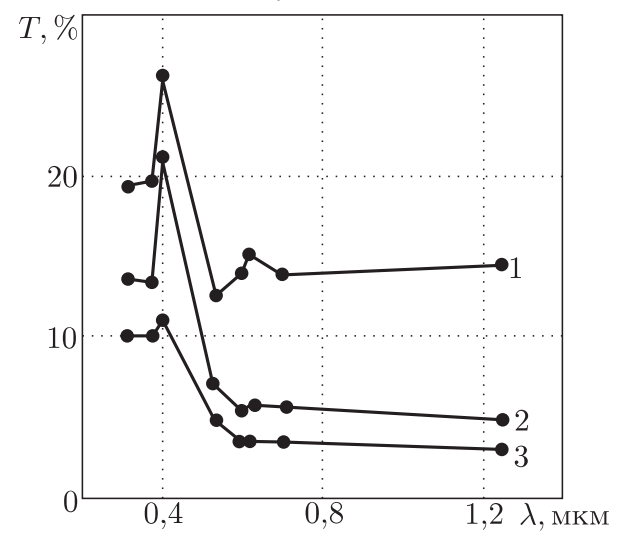

Рис. 8. Зависимости коэффициентов пропускания $T$ от длины волны излучения $\lambda$ для свеклы толщиной 0,5 мм (1); 1,0 мм (2) и 1,5 мм (3)

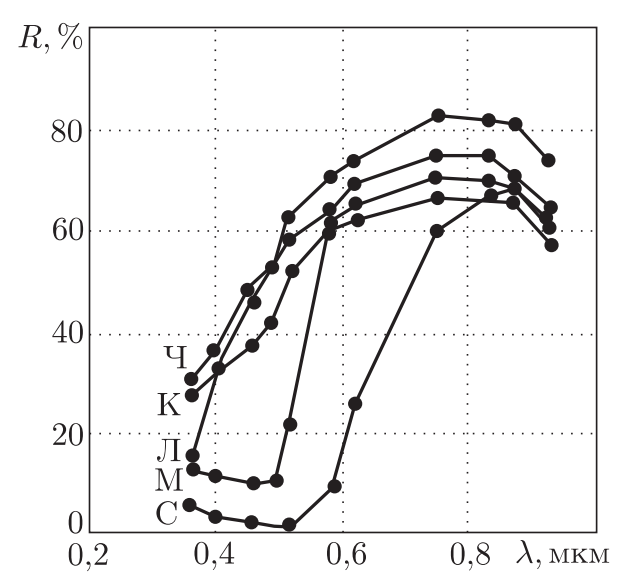

Рис. 5. Зависимости коэффициентов отражения $R$ от длины волны излучения $\lambda$ для моркови (М), свеклы (C), картофеля (K), лука (Л), чеснока (Ч)

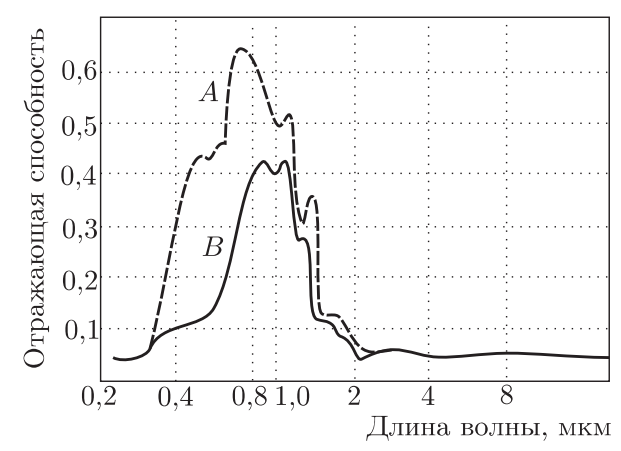

Рис. 7. Зависимость отражающей способности кожного покрова человека от длины волны излучения [5]: $A$ - слабо пигментированная кожа, $B$ - сильно пигментированная кожа

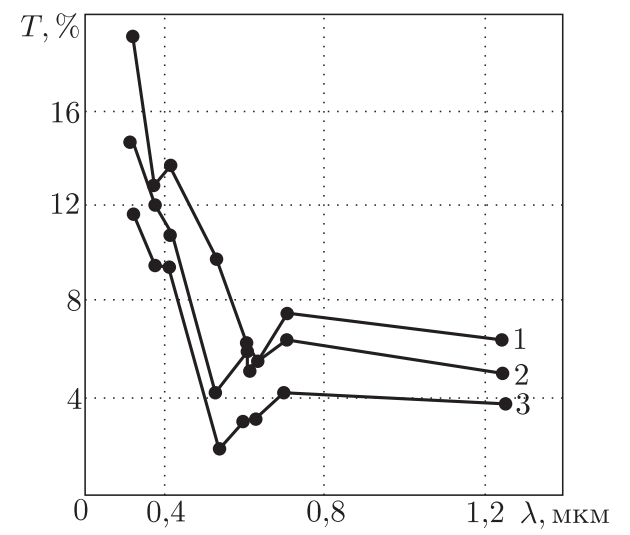

Рис. 9. Зависимости коэффициентов пропускания $T$ от длины волны излучения $\lambda$ для моркови толщиной 0,5 мм (1); $1,0 \mathrm{~mm}$ (2) и 1,5 мм (3) 


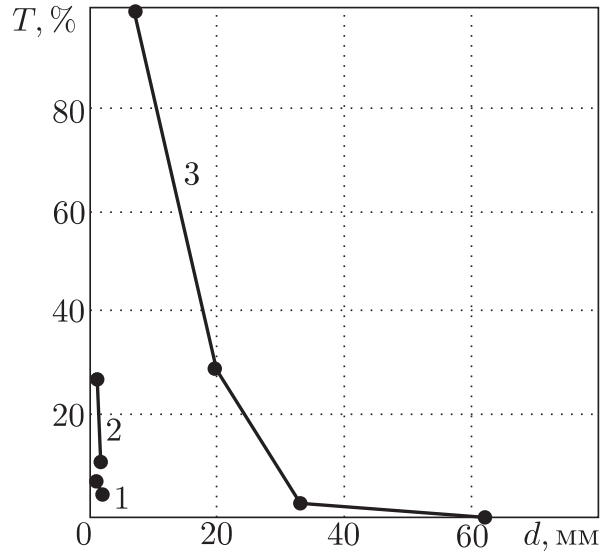

Рис. 10. Зависимости коэффициентов пропускания $T$ от толщины $d$ картофеля для различных источнико света в красной области спектра: 1 - вольфрамовая лампа накаливания, 2 - полупроводниковый лазер, 3 - гелий-неоновый лазер

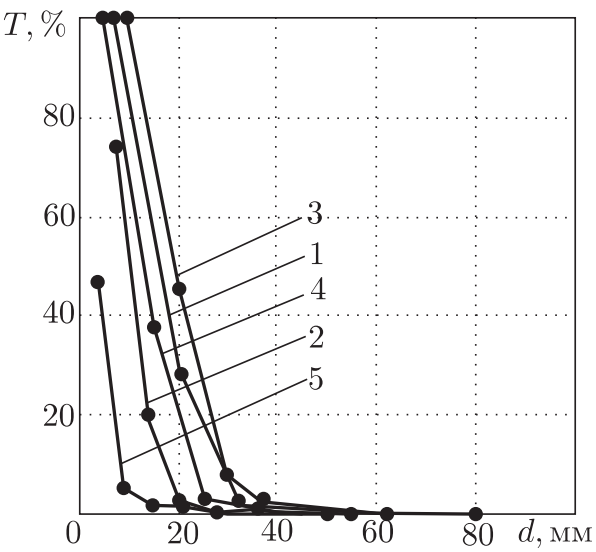

Рис. 11. Зависимости коэффициентов пропускания $T$ от толщины $d$ картофеля и моркови для излучения гелий-неонового лазера: 1 - сырой картофель, 2 - печёный картофель, 3 - сырая морковь, 4 - подсушенная морковь, 5 - сухая морковь

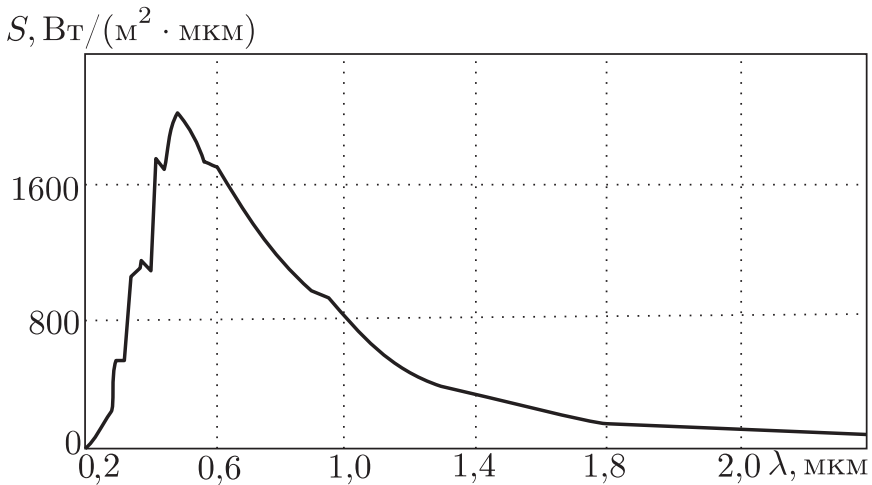

Рис. 12. Спектр излучения солнца [10]

рис. 2, приходится на инфракрасную область (рис. 13). На рис. 13 наилучшее согласие экспериментальных данных с расчётным спектром излучения по формуле Планка [11], нормированной на единицу

$$
I=\frac{\lambda_{\max }^{5}\left[\exp \left(\frac{h c}{b k}\right)-1\right]}{\lambda^{5}\left[\exp \left(\frac{h c}{b k} \frac{\lambda_{\max }}{\lambda}\right)-1\right]},
$$

достигается при $T_{ц} \approx 3,6 \cdot 10^{3} \mathrm{~K}\left(\lambda_{\max } \approx 0,800 \mathrm{MKм}\right)$.

В годы повышенной солнечной активности, сопровождаемой образованием на Солнце локальных участков с температурой, значительно превышающей $6 \cdot 10^{3} \mathrm{~K}$, максимум спектра излучения Солнца смещается в коротковолновую область (рис. 14). Мощные потоки коротковолнового (ультрафиолетового и рентгеновского) излучения совместно с потоком заряженных и электрически нейтральных частиц на время выводят биосферу Земли из состояния равновесия. Эволюционный процесс развития под благотворным влиянием солнечной энергии прерывается всплеском энергетической актив- 


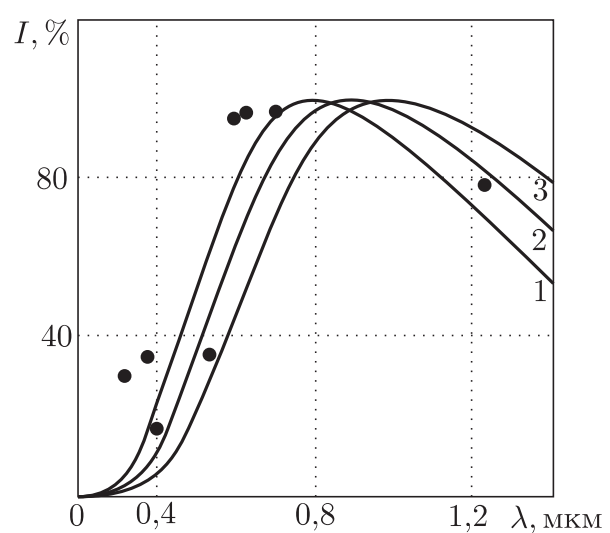

Рис. 13. Экспериментальный и рассчитанные по нормированной на единицу формуле Планка спектры излучения вольфрамовой лампы накаливания: $1-T_{ц} \approx 3,6 \cdot 10^{3} \mathrm{~K}$, $\lambda_{\max } \approx 0,800$ мкм; $2-T_{\text {ц }} \approx 3,2 \cdot 10^{3} \mathrm{~K}, \lambda_{\max } \approx$ 0,900 мкм; $3-T_{\text {ц }} \approx 2,9 \cdot 10^{3} \mathrm{~K}, \lambda_{\max } \approx 1,000 \mathrm{MKм}$
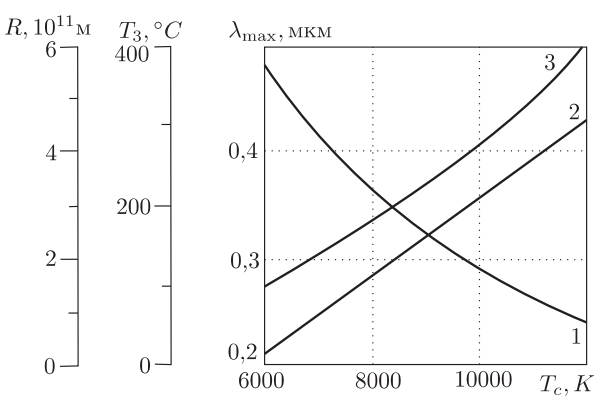

Рис. 14. Рассчитанные по приведённым в тексте формулам зависимости от температуры Солнца $T_{c}$ длины волны $\lambda_{\max }$, coответствующей максимуму спектра излучения Солнца (1), средней температуры Земли $T_{3}(2)$ и среднего радиуса земной орбиты $R(3)$

ности, что, как установил профессор А. Л. Чижевский, может служить одной из причин возникновения стихийных бедствий: наводнений, засух, землетрясений, извержений вулканов, массовых нашествий вредных насекомых, эпидемий, эпизотий (эпидемических заболеваний животных), эпифитий (эпидемических заболеваний растений), обострений сердечно-сосудистых и онкологических заболеваний и даже социальных конфликтов в обществе. Периодическое (с периодом 11,1 года) возрастание солнечной активности почти повсеместно приводит к особому изменению состава крови, к уменьшению в ней белых кровяных клеток - лейкоцитов и одновременному увеличению содержания в крови лимфоцитов, т. е. наблюдается такое изменение состава крови, как после радиоактивного облучения. Причём кровь сильнее реагирует на возрастание солнечной активности по мере приближения к полюсам Земли, где атмосфера становится особенно тонкой и проницаемой (возникают даже озоновые дыры) для солнечной радиации.

Солнечное излучение лежит в основе реакции «Ф» в крови, суть которой состоит в выпадении белковых хлопьев в сыворотке крови под воздействием определенных реактивов. Установлена прямая зависимость реакции «Ф» от суточного хода Солнца, т. е. от интенсивности его излучения. Реакция «Ф» уменьшается во время солнечных затмений как полных, так и частичных. При этом кровь почти мгновенно реагирует на изменение интенсивности солнечного излучения при затмении.

Таким образом, из анализа представленных результатов следует, что влияние световых потоков на биологические ткани в период их устойчивого развития, т. е. при нахождении биологической системы в равновесном состоянии, будет благотворным лишь при интенсивностях, сопоставимых с интенсивностью излучения спокойного Солнца в соответствующем интервале длин волн. Если же биологическая система по каким-либо причинам оказывается выведенной из состояния равновесия, то для возврата её в исходное равновесное состояние могут быть использованы световые потоки большей интенсивно- 
сти и преимущественно сине-зеленой области спектра. При этом чем больше интенсивность используемого излучения, тем меньше должно быть время его благотворного воздействия для стимулирования механизма самовозврата биологической системы в состояние равновесия. Превышение данного времени воздействия чревато раскачиванием биологической системы, что может проявиться в ослаблении защитных функций организма.

По этим причинам весьма проблематично использование лазерного излучения для повышения урожайности сельскохозяйственных культур только на этапе облучения их семян, тогда как в остальной период своего развития растения будут находиться под воздействием лишь солнечного света. Более того, при таком подходе лазерное излучение должно оказывать гнетущее воздействие на развитие растений, что, как правило, и подтверждается практикой возврата к исходной или даже снижения урожайности сельскохозяйственных культур уже во втором их поколении [3].

Можно также утверждать, что использование в лазерной терапии излучения гелий-неонового лазера не является оптимальным. Для целей терапии наибольшей эффективностью должны обладать лазеры, длины волн излучения которых приходятся на сине-зелёную область спектра. Как видно из данных таблицы, к числу таких лазеров, в частности, относятся компактные полупроводниковые лазеры ZnSe, CdS, ZnTe, из которых лазер CdS может работать при комнатной температуре, а также аргоновый лазер.

С точки зрения перспектив развития биосферы Земли под воздействием излучения Солнца, которое неизбежно рано или поздно угаснет, но перед своим угасанием должно будет пройти этап вспышки, в соответствии с данными рис. 14 в медико-биологических исследованиях важное место должно быть отведено изучению длительного воздействия коротковолнового излучения на формирование новых устойчивых состояний биологических систем, их новых жизнестойких форм. При этом следует также иметь в виду, что с повышением

Лазеры с длинами волн излучения от ближней ультрафиолетовой до ближней инфракрасной области спектра $[5,12]$

\begin{tabular}{c|c|c}
\hline Тип лазера & Тип рабочей среды & Длина волны излучения, мкм \\
\hline \multirow{4}{*}{$\begin{array}{c}\text { Газовые } \\
\text { лазеры }\end{array}$} & Аргоновый лазер & 0,$488 ; 0,515$ \\
\cline { 2 - 3 } $\begin{array}{c}\text { Твердотельные } \\
\text { лазеры }\end{array}$ & Гелий-неоновый лазер & 0,633 \\
\cline { 2 - 3 } & Рубиновый лазер & 0,694 \\
\hline \multirow{5}{*}{ Полупроводниковые } \\
\cline { 2 - 3 } лазеры & ZnS-лазер & 1,060 \\
\cline { 2 - 3 } & ZnO-лазер & 0,330 \\
\cline { 2 - 3 } & ZnSe-лазер & 0,370 \\
\cline { 2 - 3 } & CdS-лазер & 0,460 \\
\cline { 2 - 3 } & ZnТе-лазер & 0,490 \\
\cline { 2 - 3 } & СaSe-лазер & 0,530 \\
\cline { 2 - 3 } & CdSe-лазер & 0,590 \\
\cline { 2 - 3 } & CdTе-лазер & 0,675 \\
\cline { 2 - 3 } & GaAs-лазер & 0,785 \\
\cline { 2 - 3 } & InP-лазер & $0,840-0,950$ \\
\cline { 2 - 3 } & GaSb-лазер & 0,910 \\
\hline
\end{tabular}


температуры Солнца средняя температура Земли будет повышаться как

$$
T_{3}\left({ }^{\circ} \mathrm{C}\right)=T_{\mathrm{C}}(\mathrm{K}) \sqrt{\frac{R_{\mathrm{C}}}{2 R}}-273,
$$

где $R_{\mathrm{C}}=6,960 \cdot 10^{8}$ м - радиус Солнца, $R=1,496 \cdot 10^{11}$ м - средний радиус земной орбиты, $T_{\mathrm{C}}$ - температура Солнца в градусах Кельвина, $T_{3}-$ средняя температура Земли в градусах Цельсия. Чтобы средняя температура Земли с повышением температуры Солнца оставалась такой же, какой она является сейчас, $\sim 290 \mathrm{~K}$ или $\sim 17{ }^{\circ} \mathrm{C}$, необходимо, чтобы средний радиус земной орбиты возрастал как

$$
R=R_{\mathrm{C}} \frac{T_{\mathrm{C}}^{2}(K)}{2 T_{3}^{2}(K)} .
$$

Осуществление этого на практике представляется столь же маловероятным, как и организация защиты биосферы Земли от воздействия коротковолнового излучения. А это означает, что биосфера Земли под воздействием коротковолнового излучения и температуры должна будет неизбежно эволюционировать в новое устойчивое состояние.

Выводы. Таким образом, экспериментально изучены особенности взаимодействия световых потоков с биологическими тканями. На основе полученных результатов и современных представлений о влиянии Солнца на биосферу Земли дано физическое обоснование оптимального выбора лазерных источников и условий их практического применения для решения фундаментальных и прикладных задач медико-биологических исследований.

\section{БИБЛИОГРАФИЧЕСКИЙ СПИСОК}

1. Лазеры в клинической медицине / ред. проф. С. Д. Плетнёв. М.: Медицина, 1981. 400 с. [ Lasers in Clinical Medicine / ed. Prof. S. D. Pletnev. Moscow: Medicine, 1981. 400 pp.]

2. H.-P. Berlien, G. Müller, Angewandte Lasermedizin: Lehr- und Handbuch für Praxis und Klinik. Landsberg: Ecomed, 1996; русск. пер.: Х.-П. Берлиен, Г. Мюллер, Прикладная лазерная медицина: Учебное и справочное пособие. М.: Интерэксперт, 1997.

3. В. Г. Володин, В. А. Мостовников, Б. И. Авраменко, И. В. Хохлов, Лазеры и наследственность растений. Минск: Наука и техника, 1984. 175 с. [V. G. Volodin, V. A. Mostovnikov, B. I. Avramenko, I. V. Khokhlov, Lasers and Plant Genetics. Minsk: Nauka i Tekhnika, 1984. 175 pp.]

4. А. Н. Зайдель, Г. В. Островская, Ю. И. Островский, Техника и практика спектроскопии / Физика и техника спектрального анализа. М.: Наука, 1976. 392 с. [A. N. Zaidel, G. V. Ostrovskaya, Yu. I. Ostrovsky, Techniques and Practices of Spectroscopy. Moscow: Nauka, 1976. 392 pp.]

5. Реди Дж., Промышленное применение лазеров. М.: Мир, 1981. 640 с.

6. А. Л. Чижевский, Солнце и мы. М.: Знание, 1963. 48 с. [A. L. Chizhevskiy, The Sun and us. Moscow: Znanie, 1963. 48 pp.]

7. А. Л. Чижевский, Ю. Г. Шишина, В ритме Солнца. М.: Наука, 1969. 112 с. [A. L. Chizhevskiy, Yu. G. Shishina, In the Rhythm of the Sun. Moscow: Nauka, 1969. 112 pp.]

8. А. Л. Чижевский, Земное эхо солнечных бурь. М.: Мысль, 1976. 366 с. [A. L. Chizhevsky, The Terrestrial Echo of Solar Storms. Moscow: Mysl, 1976. 366 pp.]

9. А. Л. Чижевский, Космический пульс жизни. Земля в объятиях Солнца. Гелиотараксия. М.: Мысль, 1995. 766 с. [A. L. Chizhevsky, Space Pulse of Life. The Earth in the Embrace of the Sun. Geliotaraksiya. Moscow: Mysl, 1995. 766 pp.] 
10. Физические величины: Справочник/ ред. И. С. Григорьев, Е. З. Мейлихов. М.: Энергоатомиздат, 1991. 1232 с. [ Physical Quantities: Handbook/ eds. I. S. Grigoriev, E. Z. Meylikhov. Moscow: Energoatomizdat, 1991. 1232 pp.]

11. Г. С. Ландсберг, Оптика. М.: Наука, 1976. 928 с. [G. S. Landsberg, Optics. Moscow: Nauka, 1976. 928 pp.]

12. Справочник по лазерам: в 2-х томах. Т.1/ ред. А. М. Прохоров. М.: Советское радио, 1978. 504 c. [ Handbook of Lasers. Vol. 1 / ed. A. M. Prokhorov. Moscow: Sovetskoe Radio, 1978. 504 pp.]

Поступила в редакцию 04/XII/2012;

в окончательном варианте - 25/II/2013.

MSC: 78A70

\section{MEDICAL-AND-BIOLOGICAL ASPECTS OF LASER INFLUENCE}

\section{M. Gureev}

Samara State Technical University,

244, Molodogvardeyskaya st., Samara, 443100, Russia.

E-mail: anton_gureev@samaradom.ru

The distributions of reflection and admission coefficients of a different wave-length radiation by the biological tissues were experimentally studied. A physical basis of the methods of approach to an optimum selection of the laser sources and the conditions of its practical application to solution of the fundamental and applied problems of the medical-and-biological investigations was given.

Key words: laser radiation, reflection and admission coefficients, biological tissues.

Original article submitted 04/XII/2012; revision submitted $25 / \mathrm{II} / 2013$.

Dmitriy M. Gureev (Dr. Phys. \& Math. Sci.), Professor, Dept. of General Physics and Physics of Oil and Gas Production. 